\title{
Evaluation of Quality of life, Physical Activity and Nutritional Profile of Postmenopausal Women with and without Vitamin D Deficiency
}

\section{Qualidade de vida, atividade física e perfil nutricional de mulheres na pós-menopausa com e sem deficiência de vitamina $D$}

\author{
Adriele Delchiaro ${ }^{1}$ Flávia de Jesus Oliveira ${ }^{2}$ Camila Lopez Bonacordi ${ }^{3}$ Bruna Libanori Chedid ${ }^{3}$ \\ Giuliana Annicchino ${ }^{3}$ Cesar Eduardo Fernandes ${ }^{1}$ Rodolfo Strufaldi ${ }^{1} \quad$ Luciano M. Pompei $^{1}$ \\ Marcelo Luis Steiner ${ }^{1}$ \\ ${ }^{1}$ Department of Obstetrics and Gynecology, Faculdade de Medicina \\ do ABC, Santo André, SP, Brazil \\ ${ }^{2}$ Centro Integrado da Saúde da Mulher, São Bernardo dos Campos, \\ SP, Brazil \\ ${ }^{3}$ Faculdade de Medicina do ABC, Santo André, SP, Brazil \\ Address for correspondence Adriele Delchiaro, MD, Faculdade de \\ Medicina do ABC, Av. Príncipe de Gales, 821 - Vila Principe de Gales, \\ Santo André, SP, 09060-650, Brazil \\ (e-mail: dehdelchiaro@yahoo.com.br).
}

Rev Bras Ginecol Obstet 2017;39:337-343.

\begin{abstract}
Introduction Vitamin D deficiency is associated with various diseases. Prevalent in Brazil, it can result from inadequate lifestyle habits.

Objective To demonstrate that postmenopausal women with vitamin D deficiency have worse quality of health, expressed as worse quality of life, lower levels of physical activity, and worse nutritional profile.

Methods Postmenopausal women answered questionnaires about physical activity and quality of life, provided a 24-hour food record, and had serum vitamin D levels measured.

Results Among the more active women, those who perform a daily average of one hour of physical activity had vitamin D levels above $20 \mathrm{ng} / \mathrm{mL}$ (76.9\%), and those, which expose themselves to sunlight, had vitamin D levels above $30 \mathrm{ng} / \mathrm{mL}$ (34.6\%). Meanwhile the percentages for the women who are less physically active and less exposed to sunlight were $42.2 \%$ and $8.9 \%$ respectively. Being more active and more exposed to sunlight resulted in a lower fat percentage. Serum vitamin D levels were not

\section{Keywords}

- vitamin D

- menopause

- locomotor activity

- gardening correlated with quality of life.

Conclusion Walking and gardening increased serum vitamin D levels and decreased the percentage of body fat. The limitations of the study prevented the impact of 25hidroxyvitamin $\mathrm{D}$ on the quality of life and nutritional aspects of the women from being evaluated.
\end{abstract}

received

July 13, 2016

accepted

April 17, 2017

published online

June 16, 2017
DOI https://doi.org/

10.1055/s-0037-1603892.

ISSN 0100-7203.
Copyright (e 2017 by Thieme Revinter

Publicações Ltda, Rio de Janeiro, Brazil
License terms

(ㄷ) (i) $\ominus$ (5) 


\section{Resumo \\ Palavras-chave \\ - vitamina D \\ - menopausa \\ - atividade locomotora \\ - jardinagem \\ Introdução A deficiência de vitamina $D$ está associada a diversas doenças. Prevalente no Brasil, pode ser consequência de hábitos de vida inadequados. \\ Objetivo Demonstrar que mulheres na pós-menopausa com hipovitaminose D têm pior qualidade de saúde, expressa por piores qualidade de vida, nível de atividade física e perfil nutricional. \\ Métodos Mulheres na pós-menopausa responderam a questionários sobre atividade física, qualidade de vida, registro alimentar de 24 horas, e tiveram os níveis séricos de vitamina $\mathrm{D}$ medidos. \\ Resultados Dentre as mulheres mais ativas, as que praticam em média 1 hora de atividade por dia apresentaram níveis de vitamina D superiores a $20 \mathrm{ng} / \mathrm{mL}(76,9 \%)$, e as que se expõem ao sol apresentaram níveis acima de $30 \mathrm{ng} / \mathrm{mL}$ (34,6\%). Já as mulheres menos ativas e menos expostas ao sol apresentaram respectivamente $42,2 \%$ e $8,9 \%$. Ser mais ativa e ter maior exposição solar significou ter menor percentual de gordura. 0 nível sérico de vitamina $\mathrm{D}$ não mostrou relação com a qualidade de vida. \\ Conclusão Caminhada e jardinagem aumentam os níveis séricos de vitamina $D$ e diminuem o percentual de gordura corpórea. As limitações do estudo não permitiram avaliar o impacto da 25-hidróxi-vitamina $\mathrm{D}$ na qualidade de vida e nos aspectos nutricionais das mulheres.}

\section{Introduction}

Vitamin D is a hormone that has various organic functions, and is produced in the skin following exposure to sunlight, or obtained by eating foods such as fish, eggs and fortified milk. ${ }^{1}$

Observational studies have associated vitamin D deficiency as a risk factor for autoimmune, cardiovascular and metabolic diseases, infections, and malignancies. ${ }^{2}$ Furthermore, muscle relaxation and contraction are impaired by vitamin D deficiency, and are associated with pain and muscle weakness, which can increase the risk of falls in the elderly population. ${ }^{3}$

Serum vitamin D levels vary according to the geographical region, type of food, lifestyle, age, race, presence or absence of diseases, and exposure to sunlight. ${ }^{4-6}$

In Brazil, despite the tropical climate with little seasonal variation and sufficient sunshine, vitamin D deficiency is prevalent. Studies have found inadequate concentrations in $42 \%$ of the elderly people living in the city of São Paulo, and in $24 \%$ of women with osteoporosis. ${ }^{3,7}$ In healthy adolescents and young adults, the prevalence was of $60 \%$ and $50 \%$ respectively. ${ }^{8,9}$

Therefore, it is interesting to understand the reason behind this prevailing presence of individuals with vitamin D deficiency. Among the triggering factors, one can hypothesize that such individuals have a lifestyle that is inadequate for reaching and maintaining proper levels of said vitamin.

According to the World Health Organization (WHO), lifestyle is a set of habits and customs that are influenced, modified, encouraged or inhibited by the process of socialization, and have a major impact on health. ${ }^{10,11}$
Evidence has shown that changes in habits have a huge impact on the quality of life of individuals and of the population. ${ }^{12,13}$

Consequently, vitamin D deficiency in the Brazilian population can be considered due to inadequate lifestyle habits, and could serve as a marker of bad quality of health. We aimed to demonstrate that postmenopausal women with vitamin D deficiency have worse quality of health, expressed as worse quality of life, lower levels of physical activity and worse nutritional profile compared with women without vitamin $\mathrm{D}$ deficiency.

\section{Methods}

This study is a cross-sectional case-control study in which postmenopausal patients admitted at the outpatient menopause clinic of an institution in the city of São Bernardo do Campo, in the state of São Paulo, Brazil, during the period of January to July 2015, and were invited to participate in the study. The women selected were those who accepted to participate, signed the voluntary and informed consent form, and fulfilled the criteria of eligibility of the study. Said women filled in a registration form providing personal information and their past and present medical histories, answered questionnaires about physical activity, quality of life, and were referred to a nutritionist, who obtained a 24hour food record from them and performed anthropometric measurements. The study was approved by the Research Ethics Committee of the institution.

In order to be included in the study, the women needed to be in the postmenopausal stage, and be able to read, understand and sign the voluntary and informed consent form. 
Women taking vitamin D supplements at the time were not included in the study, neither were women who couldn't perform physical activities, had a questionable clinical history, or had been previously diagnosed with diseases that affect bone metabolism, such as primary hyperparathyroidism, Paget's disease, neoplasias, hypothyroidism or decompensated hyperthyroidism, kidney failure, as well as those taking lipid-lowering drugs and thyroxine, or taking medicines such as corticosteroids and calcium at the time.

\section{Nutritional Evaluation}

For the nutritional evaluation, the patients were told to fast (no food or liquids) for 4 hours before the test, and avoid excessive consumption of caffeine-rich foods. During the evaluation, anthropometric data was collected, such as weight $(\mathrm{kg})$, height $(\mathrm{cm})$, abdominal circumference $(\mathrm{cm})$ and fat percentage (\%).

The measurements were obtained using G-Tech digital scales, model Glass PRO (G-Tech International Co., Uijeongbu, Gyeonggi, South Korea), which were graduated (kg) and had coupled stadiometers $(\mathrm{cm})$ to define weight and height respectively. The same digital scales defined the fat percentage (\%). A graduated tape measure $(\mathrm{cm})$ was used to measure the abdominal circumference. The body mass index (BMI) was calculated as the weight squared $\left(\mathrm{kg}^{2}\right)$ divided by the height $(\mathrm{cm})$.

The nutritional evaluation of the patients was performed by a single nutritionist (FJO), who used the 24-hour food records and classified the patients in terms of those who had or had not eaten eggs and fish.

25 -Hydroxycholecalciferol $(25(\mathrm{OH})$ vitamin $\mathrm{D})$ was quantified according to the routine procedure for patients at the outpatient menopause clinic, with a validity of 6 months; however, in the case of patients who had been previously tested for $25(\mathrm{OH})$ vitamin $\mathrm{D}$, a $25(\mathrm{OH})$ vitamin D sample was collected during the interview with the nutritionist, and the result was subsequently analyzed. Following the evaluation of the results, the patients were divided into 2 groups: the sufficient group, which comprised those with $25(\mathrm{OH})$ vitamin $\mathrm{D} \geq 20 \mathrm{ng} / \mathrm{mL}$, and the efficient group, composed of the patients with $25(\mathrm{OH})$ vitamin $\mathrm{D}<20 \mathrm{ng} / \mathrm{mL}$.

\section{Questionnaires}

The quality of life questionnaire used was the 36-item Short Form (SF-36) Health Survey, which has items subdivided into 8 domains: physical functioning; role limitations due to physical problems; pain; general health; vitality; social functioning; role limitations due to emotional problems; and mental health. Each domain is scored from $0-100$, with 0 being the worst result for the domain, and 100, the best; this is called the Raw Scale, since the final value does not have a unit of measure. $^{14}$

The physical activity performed was evaluated using the International Physical Activity Questionnaire. This questionnaire measures the time spent doing moderate or vigorous physical activity within the domains of work, transport, housework, indoors and in the garden, and leisure during a regular week, and classifies the interviewees as 'more active' (those who perform at least moderate physical activities during more than 150 minutes per week) and 'less active' (those who perform less than 150 minutes of physical activities per week). Gardening was evaluated in terms of the hours spent doing moderate or vigorous domestic activities in the garden or backyard. This questionnaire was developed as a means of measuring the physical activity performed worldwide, and has been shown to be an efficient tool, given that the measurements obtained from it are as good as other established self-reporting measurements of physical activity. ${ }^{15}$

For the purpose of analysis, the patients of this study were also classified as follows: 'more active and exposed' patients that always walk, including walking as a means of transport and as physical activity, in addition to both moderate and vigorous activities performed in the garden, that is, outdoors, suggesting greater exposure to sunlight, for at least 420 minutes a week, that is, an average of 1 hour of activity per day; and 'less active and exposed' - those who perform less than 420 minutes of activity per week.

\section{Statistical Analysis}

The data obtained were organized on electronic spreadsheets using the Microsoft Excel 2007 software (Microsoft Corporation, Redmond, WA, US). The statistical analysis was performed using the WinSTAT software, version 2007.1 (R. Fitch Software, Bad Krozingen, Germany).

Normal distribution was tested using the KolmogorovSmirnov test. Continuous numerical data were presented in the form of mean average \pm standard deviation. The categorical data were presented as frequency and percentage.

A comparison between the groups was performed using the Student's t-test for independent samples when the continuous numerical data followed a normal distribution and the Mann-Whitney $U$ test when they did not follow normal distribution. For the categorical data, the comparisons were performed using the chi-squared test. A significance level of $5 \%$ was adopted.

\section{Results}

A total of 253 women were invited to participate in the study. Of these, 179 were not included: 50 already took vitamin D supplements; 3 did not accept to participate in the study; 94 took thyroxine or lipid-lowering drugs; 3 had been diagnosed with kidney failure; and 2 had altered bone metabolism. Of the 74 women included, only 71 were tested for 25 $(\mathrm{OH})$ vitamin D levels.

Of the population studied, 32 women had insufficient vitamin D levels, and 39 had sufficient vitamin D levels. As shown in -Table 1, the only significant difference between these two groups was garden activity, which was greater in those considered to have sufficient vitamin D levels.

- Table 2 shows the data of the quality of life evaluation, and no statistically significant differences were observed between the sufficient and insufficient vitamin D groups.

The overall average found for serum $25(\mathrm{OH})$ vitamin D levels was $22.1 \mathrm{ng} / \mathrm{mL}$. Of the white women, 15 (46.9\%) were in the 'insufficient' group, and $26(66.7 \%)$ were in the 
Table 1 Comparisons between the $25(\mathrm{OH})$ vitamin $\mathrm{D}<20 \mathrm{ng} / \mathrm{mL}$ group and the $25(\mathrm{OH})$ vitamin $\mathrm{D} \geq 20 \mathrm{ng} / \mathrm{mL}$ group for age, age of menopause, anthropometric measurements, fat percentage, total weekly walking time and garden activity

\begin{tabular}{|l|l|l|l|}
\hline & $\mathbf{2 5}(\mathrm{OH})$ vitamin $\mathrm{D}<\mathbf{2 0} \mathbf{n g} / \mathbf{m L}$ & $\mathbf{2 5}(\mathrm{OH})$ vitamin $\mathrm{D}>\mathbf{2 0} \mathbf{n g} / \mathbf{m L}$ & \\
\hline & $\mathbf{n}=\mathbf{3 2}$ & $\mathbf{n}=39$ & \\
\hline & Mean $\pm \mathrm{SD}$ & Mean $\pm \mathrm{SD}$ & $\mathbf{p}^{*}$ \\
\hline Age (years) & $54.8 \pm 7.4$ & $56.2 \pm 7.1$ & 0.433 \\
\hline Age of menopause (years) & $46.3 \pm 5.4$ & $47.6 \pm 5.6$ & 0.322 \\
\hline Weight $(\mathrm{kg})$ & $68.8 \pm 11.9$ & $64.7 \pm 11.6$ & 0.152 \\
\hline Height $(\mathrm{m})$ & $1.53 \pm 0.04$ & $1.54 \pm 0.05$ & 0.395 \\
\hline BMI $\left(\mathrm{kg} / \mathrm{m}^{2}\right)$ & $29.3 \pm 5.2$ & $27.2 \pm 4.8$ & 0.081 \\
\hline Fat $\%$ & $39.8 \pm 6.4$ & $37.1 \pm 7.7$ & 0.107 \\
\hline AC $(\mathrm{cm})$ & $97.7 \pm 10.7$ & $95.1 \pm 11.6$ & 0.335 \\
\hline Total weekly walking time $(\mathrm{min})$ & $199.4 \pm 175.0$ & $258.3 \pm 226.4$ & 0.232 \\
\hline Gardening (min) & $103.0 \pm 243.5$ & $289.9 \pm 385.4$ & 0.007 \\
\hline
\end{tabular}

Abbreviations: 25(OH) vitamin D, 25-hidroxyvitamin D; AC, abdominal circumference; BMI, body mass index; SD, standard deviation. Note: ${ }^{*} p<0.05$ : statistically significant.

'sufficient' group, with no statistical difference between the two groups ( $p=0.093)$. The intake of fish and eggs was not different $(p=0.252)$ in the comparison between the women in the groups of insufficient and sufficient vitamin levels, and $4(12.5 \%)$ and 9 (23.1\%) women had eaten fish and eggs respectively.

In the evaluation of walking + garden activities $>420$ minutes/week, a statistically significant difference $(p<0.05)$ was observed between the insufficient and sufficient groups, wherein 6 women (18.8\%) and 20 women (51.3\%) performed this activity respectively.

In the comparison between the 'less active and exposed' and 'more active and exposed' groups, shown in - Table 3, it was noted that the latter had greater total weekly walking time, garden activity, 25( $\mathrm{OH})$ vitamin D levels, and a lower fat percentage, all differences being statistically significant $(p<0.001)$. Weight and BMI, although lower in the 'more active and exposed' group, showed no significant differences ( $p=0.08$ and $p=0.07$ respectively).

In - Table 4, the quality-of-life evaluation data are shown, and no statistically significant differences were observed between the 'less active and exposed' and 'more active and exposed' groups.

There were 17 (37.8\%) white women in the 'less active and exposed' group, and $13(50.0 \%)$ in the 'more active and exposed' group $(p=0.316)$. There were 8 women $(17.8 \%)$ who reported fish and egg intake in the 'less active and exposed' group. and 5 (19.2\%) in the 'more active and

Table 2 Quality of life evaluation of the $25(\mathrm{OH})$ vitamin $\mathrm{D}<20 \mathrm{ng} / \mathrm{mL}$ group and the $25(\mathrm{OH})$ vitamin $\mathrm{D} \geq 20 \mathrm{ng} / \mathrm{mL} \mathrm{group}$

\begin{tabular}{|l|l|l|l|}
\hline & $\mathbf{2 5}(\mathrm{OH})$ vitamin $\mathbf{D}<\mathbf{2 0} \mathbf{n g} / \mathbf{m L}$ & $\mathbf{2 5}(\mathrm{OH})$ vitamin $\mathbf{D}>\mathbf{2 0} \mathbf{n g} / \mathbf{m L}$ & \\
\hline & $\mathbf{n}=\mathbf{3 2}$ & $\mathbf{n}=39$ & $\mathbf{P}^{*}$ \\
\hline & Mean \pm SD & Mean \pm SD & 0.580 \\
\hline $\begin{array}{l}\text { Physical functioning } \\
\text { problems }\end{array}$ & $75.6 \pm 23.1$ & $78.1 \pm 22.3$ & 0.092 \\
\hline General health & $57.0 \pm 42.7$ & $73.7 \pm 37.6$ & 0.808 \\
\hline Pain & $55.1 \pm 19.1$ & $52.8 \pm 19.9$ & 0.617 \\
\hline Vitality & $52.8 \pm 22.5$ & $54.9 \pm 20.7$ & 0.282 \\
\hline Social functioning & $58.9 \pm 20.7$ & $53.7 \pm 15.3$ & 0.644 \\
\hline $\begin{array}{l}\text { Role limitations due to emo- } \\
\text { tional problems }\end{array}$ & $73.9 \pm 26.7$ & $72.6 \pm 25.5$ & 0.554 \\
\hline Mental health & $62.5 \pm 46.2$ & $69.2 \pm 42.8$ & 0.328 \\
\hline
\end{tabular}

Abbreviation: SD, standard deviation.

Note: ${ }^{*} p<0.05$ : statistically significant. 
Table 3 Comparisons between the 'less active and exposed' and 'more active and exposed' groups for age, age of menopause, anthropometric measurements, fat percentage, and physical activity

\begin{tabular}{|l|l|l|l|}
\hline & Less active and exposed & More active and exposed & \\
\hline & $\mathbf{n}=\mathbf{4 5}$ & $\mathbf{n}=\mathbf{2 6}$ & \\
\hline & Mean \pm SD & Mean \pm SD & $\boldsymbol{p}^{*}$ \\
\hline Age (years) & $55.1 \pm 6.8$ & $56.5 \pm 8.0$ & 0.424 \\
\hline Age of menopause (years) & $46.5 \pm 6.1$ & $47.8 \pm 4.3$ & 0.359 \\
\hline Weight $(\mathrm{kg})$ & $68.3 \pm 10.7$ & $63.4 \pm 13.2$ & 0.088 \\
\hline Height $(\mathrm{m})$ & $1.54 \pm 0.05$ & $1.54 \pm 0.05$ & 0.692 \\
\hline BMI $\left(\mathrm{kg} / \mathrm{m}^{2}\right)$ & $29.0 \pm 4.4$ & $26.7 \pm 5.8$ & 0.076 \\
\hline Fat \% & $39.9 \pm 5.5$ & $35.5 \pm 9.0$ & 0.028 \\
\hline AC $(\mathrm{cm})$ & $97.5 \pm 10.1$ & $94.1 \pm 12.9$ & 0.212 \\
\hline $25(\mathrm{OH})$ vitamin D $(\mathrm{ng} / \mathrm{mL})$ & $19.7 \pm 7.9$ & $26.2 \pm 7.7$ & 0.001 \\
\hline Total weekly walking time (min) & $143.2 \pm 102.6$ & $385.0 \pm 247.5$ & $<0.001$ \\
\hline Gardening (min) & $41.3 \pm 56.0$ & $490.0 \pm 430.8$ & $<0.001$ \\
\hline
\end{tabular}

Abbreviations: 25(OH) vitamin D, 25-hidroxyvitamin D; AC, abdominal circumference; BMI, body mass index; SD, standard deviation. Note: ${ }^{*} p<0.05$ : statistically significant.

exposed' group, but no difference was observed between them $(p=0.879)$.

-Fig. 1 compares vitamin levels, stratified into four groups, for women classified as 'less active and exposed' and 'more active and exposed'. In the evaluation of the groups, none of the women in the 'more active and exposed' group had vitamin D levels below $10 \mathrm{ng} / \mathrm{mL}$, while $57.9 \%$ of those in the 'less active and exposed' group had levels below $20 \mathrm{ng} / \mathrm{mL}$. In general, Fig. 1 shows that an almost linear relationship between physical activity and sunlight exposure and vitamin $\mathrm{D}$ levels is found in the study population.

\section{Discussion}

The results of this study demonstrate that higher $25(\mathrm{OH})$ vitamin $\mathrm{D}$ levels and lower body fat percentage are exhibited by postmenopausal women who perform more physical activity and gardening in outside environments.

The time spent gardening was different between the groups with sufficient $(>20 \mathrm{ng} / \mathrm{mL})$ and insufficient $(<20$ $\mathrm{ng} / \mathrm{mL}) 25(\mathrm{OH})$ vitamin D levels, being significantly higher in the first. In general, this activity is performed outdoors, which increases sunlight exposure and consequently increases $25(\mathrm{OH})$ vitamin D levels.

Exposure of the skin to sunlight is fundamental for the endogenous production of $25(\mathrm{OH})$ vitamin $\mathrm{D}$, and explains the influence of outdoor physical activities on the best levels of said vitamin. Studies evaluating $25(\mathrm{OH})$ vitamin D levels have demonstrated that people admitted to hospitals and elderly people living in nursing homes have $25(\mathrm{OH})$ vitamin D levels that are considered to be insufficient. ${ }^{16-18}$ Similarly, a research performed with Muslim Moroccan women, who

Table 4 Quality of life evaluation of the 'less active and exposed' and 'more active and exposed' groups

\begin{tabular}{|l|l|l|l|}
\hline & Less active and exposed & More active and exposed & \\
\hline & $\mathbf{n}=\mathbf{4 5}$ & $\mathbf{n}=\mathbf{2 6}$ & $\mathbf{p}^{*}$ \\
\hline & Mean \pm SD & Mean \pm SD & 0.516 \\
\hline Physical functioning & $76.3 \pm 22.1$ & $78.1 \pm 23.6$ & 0.792 \\
\hline $\begin{array}{l}\text { Role limitations due to physical } \\
\text { problems }\end{array}$ & $65.6 \pm 40.7$ & $67.3 \pm 41.1$ & 0.710 \\
\hline General health & $53.5 \pm 22.6$ & $54.7 \pm 19.5$ & 0.124 \\
\hline Pain & $56.9 \pm 19.1$ & $48.5 \pm 19.2$ & 0.418 \\
\hline Vitality & $54.3 \pm 18.0$ & $59.0 \pm 18.0$ & 0.624 \\
\hline Social functioning & $73.7 \pm 27.4$ & $72.4 \pm 23.6$ & 0.765 \\
\hline $\begin{array}{l}\text { Role limitations due to } \\
\text { emotional problems }\end{array}$ & $66.7 \pm 45.5$ & $65.4 \pm 42.7$ & 0.938 \\
\hline Mental health & $65.2 \pm 20.5$ & $65.1 \pm 22.8$ & \\
\hline
\end{tabular}

Abbreviation: SD, standard deviation.

Note: ${ }^{*} p<0.05$ : statistically significant. 


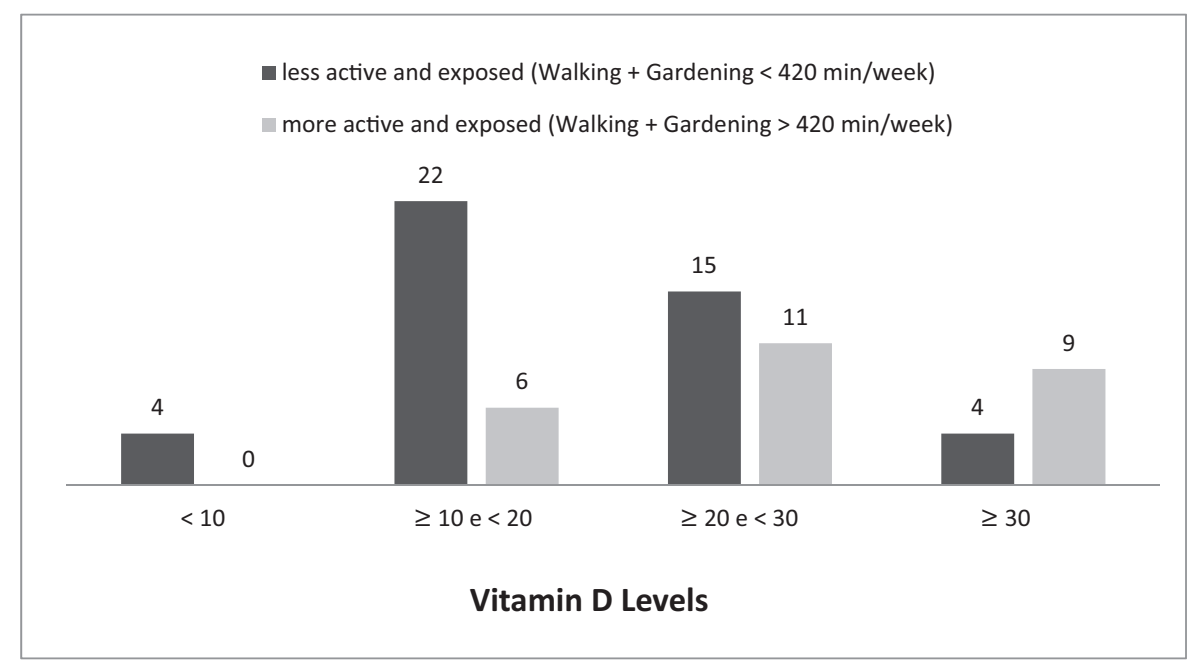

Fig. 1 Participant distribution according to $25(\mathrm{OH})$ vitamin D levels for the 'less active and exposed' (walking + gardening $<420$ minutes/ week) and the 'more active and exposed' (walking + gardening $>420$ minutes/week) groups.

use a veils and have low exposure to sunlight, found that $91 \%$ of them had insufficient $25(\mathrm{OH})$ vitamin D serum levels. ${ }^{5}$

Women considered to be more active and more exposed to sunlight had higher $25(\mathrm{OH})$ vitamin D levels in comparison with women who were less active and less exposed to sunlight. The distribution of the various increasing $25(\mathrm{OH})$ vitamin D levels showed a negative correlation for the women who are 'less active and exposed,' and a positive correlation for the other group. It is noted that outdoors activities have a positive impact on $25(\mathrm{OH})$ vitamin D levels.

In recent years, observational studies have associated adequate vitamin $\mathrm{D}$ levels as a protective factor for various diseases, leading to increased monitoring of the serum levels of said vitamin and preventative supplementation. ${ }^{2}$ However, the determining mechanisms of these apparent benefits are unclear, and even the supplementation thereof can be considered to be dependent on the evaluated outcome. ${ }^{19,20}$ Furthermore, it is questioned whether low serum levels could be a marker for poor quality of health, with the recommendation being to improve the lifestyle habits prior to the supplementation, a more suitable therapeutic approach. 2,19,20

It is also highlighted that women with greater sunlight exposure spend more time performing physical activities and have less body fat, which are two factors classically associated with protection against cardiovascular diseases, several cancers and even mental diseases. ${ }^{2}$ Consequently, since $25(\mathrm{OH})$ vitamin D levels also increased as a result of greater sunlight exposure, one can infer that an adequate level of $25(\mathrm{OH})$ vitamin $\mathrm{D}$ is a characteristic of people with a healthy lifestyle and, consequently, with a lower incidence of the aforementioned diseases.

The population of more active and exposed women, as expected, also spent more time walking, more time gardening, and tended to have lower BMIs. Interestingly, physical activity and gardening were related to better quality of health. ${ }^{21-23}$ As such, a lower percentage of body fat, lower weight and BMI are considered to be markers of better quality of health. ${ }^{23}$ It is also inferred that serum $25(\mathrm{OH})$ vitamin D levels could be a marker of quality of health in the population of this study.

In the evaluation of the relationship between quality of life and serum 25(OH) vitamin D levels or performing physical activities outdoors, no difference was observed between the groups. The sample size could be an explanation for the lack of relationship, considering that evidence has shown that physical activity, gardening and $25(\mathrm{OH})$ vitamin $\mathrm{D}$ are associated with better quality of life. ${ }^{24-26}$

We highlight that, although there is no significant difference between the $25(\mathrm{OH})$ vitamin $\mathrm{D}>20 \mathrm{ng} / \mathrm{mL}$ and the 25 $(\mathrm{OH})$ vitamin $\mathrm{D}<20 \mathrm{ng} / \mathrm{mL}$ groups, the domain 'role limitations due to physical problems' shows a tendency toward women with lower $25(\mathrm{OH})$ vitamin D levels. Women with physical problems supposedly find it more difficult to perform physical activities outdoors, and therefore have lower $25(\mathrm{OH})$ vitamin D levels. However, one cannot discard the possibility of the opposite being true, making it difficult to explain this result.

The average $25(\mathrm{OH})$ vitamin $\mathrm{D}$ serum level found in the population of this study was $22.1 \mathrm{ng} / \mathrm{mL}$. Despite the lack of consensus in the literature regarding the ideal serum level, ${ }^{19}$ the majority were considered to have sufficient levels. In the city of São Paulo, the majority of the elderly population (58\%), men and women, have sufficient $25(\mathrm{OH})$ vitamin D serum levels, using $25 \mathrm{ng} / \mathrm{mL}$ as a reference value. ${ }^{3}$

The nutritional approach was direct and objective, and was performed by a single nutritionist, which is one of the strong points of this study. In order to evaluate a diet rich in $25(\mathrm{OH})$ vitamin $\mathrm{D}$, the intake of fish and eggs was taken into consideration. It was noted, however, that the majority of participants do not eat a good quantity of these foods, jeopardizing the evaluation. However, it is noted that out of the 13 women who ate eggs and fish, 9 had better $25(\mathrm{OH})$ vitamin D levels, corresponding to $23.1 \%$ of the 39 women with $25(\mathrm{OH})$ vitamin $\mathrm{D}>20 \mathrm{ng} / \mathrm{mL}$.

Among the limitations of this study, we can cite the reduced number of participants included. The reason for 
this was the large number of postmenopausal women admitted at the outpatient menopause clinic who were taking $25(\mathrm{OH})$ vitamin D supplements or medicines that could interfere in the result.

In conclusion, this study demonstrates that outdoors physical activity is associated with higher $25(\mathrm{OH})$ vitamin D serum levels and decreases the percentage of body fat in postmenopausal women. The limitations of the study prevented the impact of $25(\mathrm{OH})$ vitamin $\mathrm{D}$ on the quality of life and nutritional aspects of the women from being evaluated.

\section{References}

1 Alves M, Bastos M, Leitão F, Marques G, Ribeiro G, Carrilho F. Vitamina D - importância na avaliação laboratorial. Rev Port Endocrinol Diabetes Metab. 2013;8(01):32-39

2 Theodoratou E, Tzoulaki I, Zgaga L, Ioannidis JP. Vitamin D and multiple health outcomes: umbrella review of systematic reviews and meta-analyses of observational studies and randomised trials. BMJ 2014;348:g2035

3 Saraiva GL, Cendoroglo MS, Ramos LR, et al. Influence of ultraviolet radiation on the production of 25 hydroxyvitamin $D$ in the elderly population in the city of São Paulo (23 degrees 34'S), Brazil. Osteoporos Int 2005;16(12):1649-1654

4 Grant WB. Vitamin D and health: implications for high-latitude countries. J Orthomol Med 2006;21(01):37-47

5 Allali F, El Aichaoui S, Khazani H, et al. High prevalence of hypovitaminosis D in Morocco: relationship to lifestyle, physical performance, bone markers, and bone mineral density. Semin Arthritis Rheum 2009;38(06):444-451

6 Holick MF. Vitamin D: photobiology, metabolism, and clinical applications. In: DeGroot LJ, Besser M, Burger HG, Jameson JL, Loriaux DL, Marshall JC, et al., editors. Endocrinology. 3rd ed. Philadelphia: WB Saunders; 1995. vol. 2, p. 990-1014

7 Genaro PS, Pereira GAP, Pinheiro MM, Szejnfeld VL, Martini LA. Relationship between nutrient intake and vitamin D status in osteoporotic women. Int J Vitam Nutr Res 2007;77(06):376-381

8 Peters BSE, dos Santos LC, Fisberg M, Wood RJ, Martini LA. Prevalence of vitamin D insufficiency in Brazilian adolescents. Ann Nutr Metab 2009;54(01):15-21

9 Maeda SS, Kunii IS, Hayashi L, Lazaretti-Castro M. The effect of sun exposure on 25-hydroxyvitamin D concentrations in young healthy subjects living in the city of São Paulo, Brazil. Braz J Med Biol Res 2007;40(12):1653-1659

10 U.S. Department of Health and Human Services. Healthy People 2010: understanding and improving health. 2nd ed. Washington, DC: U.S. Government Printing Office; 2000

11 World Health Organization. A glossary of terms for community health care and services for older persons. Geneva: WHO; 2004.
(WHO Centre for Health Development, Ageing and Health Technical Report, vol. 5)

12 Guyatt GH, Ferrans CE, Halyard MY, et al; Clinical Significance Consensus Meeting Group. Exploration of the value of health-related quality-of-life information from clinical research and into clinical practice. Mayo Clin Proc 2007;82(10): 1229-1239

13 Li C, Ford ES, Mokdad AH, Jiles R, Giles WH. Clustering of multiple healthy lifestyle habits and health-related quality of life among U.S. adults with diabetes. Diabetes Care 2007;30(07): 1770-1776

14 Ciconelli RM, Ferraz MB, Santos W, Meinão I, Quaresma MR. Tradução para a língua portuguesa e validação do questionário genérico de avaliação da qualidade de vida SF-36 (Brasil SF-36). Rev Bras Reumatol 1999;39(03):143-150

15 Matsudo S, Araújo T, Matsudo V, et al. Questionário internacional de atividade física: estudo de validade e reprodutibilidade no Brasil. Rev Bras Ativ Fís Saúde. 2001;6(02):5-18

16 Gloth FM III, Gundberg CM, Hollis BW, Haddad JG Jr, Tobin JD. Vitamin D deficiency in homebound elderly persons. JAMA 1995; 274(21):1683-1686

17 Goldray D, Mizrahi-Sasson E, Merdler C, et al. Vitamin D deficiency in elderly patients in a general hospital. J Am Geriatr Soc 1989;37(07):589-592

18 Thomas MK, Lloyd-Jones DM, Thadhani RI, et al. Hypovitaminosis D in medical inpatients. N Engl J Med 1998;338(12):777-783

19 Michaëlsson K. The puzzling world of vitamin D insufficiency. Lancet Diabetes Endocrinol 2014;2(04):269-270

20 Bolland MJ, Grey A, Gamble GD, Reid IR. The effect of vitamin D supplementation on skeletal, vascular, or cancer outcomes: a trial sequential meta-analysis. Lancet Diabetes Endocrinol 2014;2 (04):307-320

21 Beitz R, Dören M. Physical activity and postmenopausal health. J Br Menopause Soc 2004;10(02):70-74

22 De Rui M, Toffanello ED, Veronese N, et al. Vitamin D deficiency and leisure time activities in the elderly: are all pastimes the same? PLoS One 2014;9(04):e94805

23 Hawkins JL, Smith A, Backx K, Clayton DA. Exercise intensities of gardening tasks within older adult allotment gardeners in Wales. J Aging Phys Act 2015;23(02):161-168

24 Vagetti GC, Barbosa Filho VC, Moreira NB, Oliveira Vd, Mazzardo $\mathrm{O}$, Campos Wd. Association between physical activity and quality of life in the elderly: a systematic review, 2000-2012. Rev Bras Psiquiatr 2014;36(01):76-88

25 Lidén E, Alstersjö K, Gurné FL, Fransson S, Bergbom I. Combining garden therapy and supported employment - a method for preparing women on long-term sick leave for working life. Scand J Caring Sci 2016;30(02):411-418

26 Hoffmann MR, Senior PA, Mager DR. Vitamin D supplementation and health-related quality of life: a systematic review of the literature. J Acad Nutr Diet 2015;115(03):406-418 